\title{
Dividend Policy and Companies' Financial Performance
}

\author{
Raed KANAKRIYAH ${ }^{1}$
}

Received: August 01, 2020 Revised: September 06, 2020 Accepted: September 10, 2020

\begin{abstract}
This study aims to determine the nature of the association between dividend policy and a corporation's financial performance in emerging countries, as well as the main variables that may have an effect on financial performance. The study included 92 industrial and service sector companies listed on the Amman Stock Exchange (ASE) during the period from 2015 to 2019. The study used Panel Data Analysis and cross-sectional time-series data and simple and multiple linear regression models. A multiple regression model was also developed in order to test whether guess factors may have a possible impact on financial performance (such as Dividend Yield, Dividend Pay-out Ratio, Firm Size, Leverage Ratio, Current Ratio). The data was collected from the annual reports and information that was available on the ASE website covering the period from 2015 to 2019. The results detect a strong relation between DY, DPR, and FSIZE variables that explain firm performance. Also leverage ratio is negatively and significantly associated with ROA and AOE. Moreover, no relations were detected between current ratio and financial performance. The study's conclusion is that dividend policy explains a lot of a company's financial performance, meaning that the dividend policy has a statistically significant impact on company financial performance.
\end{abstract}

Keywords: Dividend Policy, Financial Performance, Dividend Yield, Dividend Pay-Out Ratio, Firm Size

JEL Classification Code: M41, G32, G35, G51

\section{Introduction}

The financial markets are considered a pivotal and important component and represent the main means of communication between corporations and accounting information users. Investors that mobilise savings and convert them into investments contribute to economic development. This provides a solid base for the economy. Recent changes in the economics and financial field have led companies to search for ways and methods that enable them to continue to achieve acceptable levels of performance, especially financial performance, and many researchers have studied the financial decisions that aim to maximise a corporation's value, not only the distribution of profits to owners (shareholders) but also the precarious

${ }^{1}$ First Author and Corresponding Author. Assistant Professor, Accounting Department, Business School, Al-Balq'a Applied University, Jordan [Postal Address: Al-Salt, Jordan]

Email: kraed71@bau.edu.jo

(c) Copyright: The Author(s)

This is an Open Access article distributed under the terms of the Creative Commons Attribution Non-Commercial License (https://creativecommons.org/licenses/by-nc/4.0/) which permits unrestricted non-commercial use, distribution, and reproduction in any medium, provided the original work is properly cited. conditions experienced by corporations which lead to more difficulty in decision making which may have a significant impact on company performance and company financial performance.

Therefore, dividend policy is considered one of the most important financial decisions that can affect a company's financial performance. Dividends are considered an important element that enters into the self-financing process and company investment decisions, if those decisions depend on the available cash resulting from operational activities, as well as the effects these decisions may have on the investment opportunities available to companies. Although it is still a matter of controversy between researchers and financial analysts, dividend policy is characterised by ambiguity and failure to understand all of its aspects. The current study tries to remove these ambiguities and focus this issue through an analyses of the impact of dividend policy on company financial performance in emerging economies such as Jordan.

Many studies have been conducted to discuss this issue, the most famous of which is the hypothesis of Miller and Modigliani (1961), which confirmed that the dividend policy has no effect on the market value of the corporation or its financial performance. The question, however, is whether 
this result will be the same in emerging economics such as Jordan. The Amman Stock Exchange is considered one of the active Arab financial markets and includes a large number of different sectors with different companies that attach great importance to dividend policy. There is thus a need to measure the impact of dividends on performance in emerging countries. Based on the above, the research problem is embodied in the following main question: Does the dividend policy affect the financial performance of companies listed on the Amman stock exchange during the period from 2015 to 2019 ?

\section{Theoretical Framework for Dividend Policy}

Dividend policy means how much cash is distributed to shareholders. Dividend policy can be determined through two important elements, the first is the decision to pay dividends to shareholders and the second is to retain the profits to reinvest them in future projects. The company is responsible for balancing the need to maximise the wealth of the company's owners with the need to provide sufficient funds to finance growth projects, which is a major role that acts as a mechanism to control administrative opportunism.

Companies carry out many activities through which they seek to achieve profits. A corporation finds itself with two options for the funds that it obtains, to either distribute part of the profit to investors (dividends) or keep a portion of the profit to reinvest later for the purposes of expansion and growth, taking into account that the decision to distribute the profits is of great importance to the owners, there is a missing link between distribution and growth, and the policy of dividend distribution can be determined through balancing the level of distribution and the rate of growth. Since growth is one of the components of the distribution model, the issue of distributions is considered on the basis of choosing between current cash distributions after an evaluation of the company's current situation and its ability to exploit the profits in the expansion projects and opportunities for growth.

The decision to distribute dividends is one of the powers of the Board of Directors, which is affected by sums of factors. The most important factors for controlling distribution proportions include the corporation's financial ability, its aspirations for the future and the wishes of investors. The amount of distributions is an important matter for both the corporation and its investors; thus, there are a set of factors that can influence dividend policies:

Legal Legislation: Legal rules and legislation are differentiated among countries and affect profit distribution policy, usually based on four main rules: net profit rule, weak capital rule, the insolvency rule and the tax penalty rule. These rules are considered binding restrictions for institutions when setting the framework for dividend policy.
Profitable Investment Opportunities: If the institution does not have any profitable investment opportunities, it distributes profits to its shareholders. But if the institution has profitable investment opportunities, it will resort to using the profits achieved to fund those opportunities.

Current Shareholders' Needs (Preferences): The preferences of the current shareholders are considered one of the most important determinants of the dividend policy. In institutions in which ownership is limited to a small number of individuals, there is a clear trend towards capturing a high percentage of profits and distributing a small percentage to shareholders, as the current shareholders prefer to secure the company's financing needs through these profits (retained earnings) rather than through the issuance of new shares. The issuance of new shares leads to the entry of new shareholders, and current shareholders do not want to lose control or borrow until they bear the expenses (interest) of the loans.

Availability of Cash Liquidity: This is considered an important indicator because the distributed profits represent external cash flows. Therefore, the better an institution's position in terms of liquidity, the greater its ability to pay dividends.

Growth and Expansion Projects: An institution that is going through a growth stage will need to have financial resources available to fund growth projects. Reliance on selffinancing sources may be better than resorting to external financing sources (borrowing), and this calls for institutions to retain profits because this will save the interest expense that results from borrowing.

Factors Relating to Owners and Capital Markets: Dividend policy is affected by the owners' wants and needs. In addition, it is affected by the capital markets through the adoption of a low dividend pay-out ratio.

\subsection{Theories Explaining the Dividend Policy}

Dividend policy is considered an important strategic financial decision and it is subject to several considerations in its determination. There are many theories that try to explain the behaviour of investors towards the dividend policy, and these theories differ between supportive and neutral towards the impact of the dividend distribution policy on company financial performance. The most important of the theories that have attempted to explain distribution policy are:

\subsubsection{Neutral Theory (Dividend Policy)}

The credit for discovering this theory goes to two economists M\&M (Modigliani \& Miller, 1961). According to this theory, the profit distribution decision has no effect on the stock price in the market or the market value of the corporation. Instead, corporation value is affected only by the 
profits achieved and the risks to which the corporation's assets or investments could be exposed. Thus, the corporation's market value is affected only by the income generated from asset management and not by how this income is divided among shareholders through cash distributions or retained earnings. These authors affirmed that investment efficiency is the main determinant of shareholder wealth; they also found that investors do not distinguish between obtaining cash through distributions or the corporation's reinvestment of its profits to achieve growth, which, in turn, leads to an increase in the wealth of owners. They further said that the concept of capital gains is based on increasing the market price of shares that are held before declaring dividend distributions; if the corporation has achieved profits and decided to distribute part of it, the market value of the shares will decrease by the amount of the dividends, and if the corporation has decided to retain the profits as retained earnings, the market value of the shares will increase by the amount of retained earnings. This theory's validity does not match reality as determined from (M\&M), so their theory is unrealistic and needs more investigation or scientific testing.

\subsubsection{Bird-In-The-Hand Theory}

This theory developed by Gordon and Litner is attributed to the first theory, namely, the neutral theory of dividend policy, which stated that there is no relation between the profit distribution policy and the stock price or corporation value. It resulted as a criticism of previous theory (M\&M theory). This theory indicates that the dividend policy has a direct impact on the market value of the corporation through its effect on the market share price because the required rate of return on the funds owned decreases with the increase in dividends. This is due to the fact that the degree of investor certainty about the obtainment of capital gains realised from the retained earnings is less than the degree of certainty obtained from the capitalization of dividends, as the degree of risk increases as a result of the high uncertainty from retaining profits and reinvesting them. This means that investors prefer to distribute profits over achieving capital gains in the future, since the profits distributed today are more certain than the possibility of obtaining future capital gains.

\subsubsection{Tax Preference Theory}

According to this theory, if capital gains related to the sale of shares are not subject to tax, or if the tax rate on these profits is less than the tax rate on cash dividends distributed, investors prefer that corporations do not distribute cash dividends but retain profits in the form of profits undistributed. The lower the percentage of cash dividends at the expense of undistributed profits, the higher the shareholders' wealth, with other factors remaining constant.
Investors will therefore demand that corporations distribute large amounts of cash dividends with greater returns than they accept from other corporations. Thus, corporations distribute cash dividends in order to compensate for the amount of taxes that investors will pay.

\subsubsection{Signal Theory}

This theory states that managers use the payment of dividends as a signal to communicate private information about the corporation to external investors and shareholders about the prospect for profits and their successful performance (excellent management). Therefore, a higher distribution will give a signal to investors that the corporation's prediction of future earnings is positive; in other words, if the distribution was less than the dividend - but paying with a higher percentage - investors expect the company value to rise and if the investors expected a high percentage of the dividends, while the corporation paid a much lower percentage, the price of the shares will drop in the financial market.

\subsubsection{Clientele Effect Theory}

This theory suggests that due to the changes in dividend policies, investors always make decisions depending on the dividend polices chosen by firms which may encourage investors to continue with this firm or transfer to another firm.

\subsubsection{Agency Theory}

According to this theory, investors want to increase their cash gains by the distribution of a greater percentage of profits, while management prefers to increase the portion of retained earnings to ensure the availability of enough funds for investment or expansion purposes, leading to agency conflict.

\subsection{Dividend Forms}

There are many ways to distribute profits to shareholders; among them, we find the following:

\subsubsection{Stable Dividend Policy}

This mechanism includes the process of distributing profits on a regular basis (fixed rate), thus satisfying the shareholders wants and overcoming the problems of fluctuation in profits by always paying minimum dividends every year.

\subsubsection{Progressive Dividend Policy}

This represents the process of distributing dividends in line with the realised profits and increasing the earnings per share. 


\subsubsection{Regular Dividend Policy}

In accordance with this policy, regular profits are distributed to all shareholders every year. In the event that the profits are large and unnatural, these profits are kept in retained earnings and the excess profits will not be distributed to the shareholders.

\subsubsection{Irregular Dividend Policy}

This mechanism uses the policy of distributing profits in an irregular manner. Companies always resort to this mechanism when there is no fixed level or stability in profits or no continuity in achieving profits or the company does not have sufficient liquidity.

\subsubsection{Scrip Dividends}

These dividends are always known as liability profits and are distributed to shareholders in the form of a certificate instead of cash dividends. They provide an option for the shareholders to obtain profits at a later time or to obtain additional shares. Companies issue such profits when they don't have sufficient cash to pay cash dividends.

\subsubsection{Non-Cash Dividends}

In this policy, corporations resort to distributing new shares to shareholders instead of paying cash dividends. This procedure requires the corporation to possess reserves and profits that are heavily withheld (retained earnings) along with a desire to retain earnings and reserves to future periods based on promising investment opportunities. Fundamentally, however, the negative effect of this policy is the decrease in the share market value, so corporations resort to this policy when the stock's market value increases significantly, but a decrease is feared in the number of investors wishing to buy shares. Also, this type of distribution is characterised by not being taxed, and this process adjusts the ownership of shareholders, so that each shareholder has a greater proportion from dividends without making any changes to shareholder wealth.

\subsubsection{Shares Split}

This policy is another alternative to the distribution of cash dividends. This technique could be defined as the procedure which results in additional shares and leads to an increase in the number of shares by reducing the nominal value of the stock, usually used to create demand for shares by increasing the number of shares in the capital of the corporation. This process leads to a decrease in the dividend per share when the amount of the dividends is fixed or to the stability of the dividends per share with an increase in the amount of the total dividends. It should be noted that there is a similarity between the derivation of shares and distributions of shares in financial terms.

\subsubsection{Share Buybacks (Reverse Stock Splits)}

This policy is the inverse of the derivation of the number of its shares. As appears from its name, this policy is based on the same principle of the derivation process of shares but in an inverse way which leads to raising the nominal value of the share. Therefore, there is no change in the financial structure of the corporation except for the number of shares. The reverse derivation method is a policy to prevent the stock price from falling to low levels. Stock repurchase (treasury shares), as the corporation's buyback of its shares, is intended to use the surplus of cash in the corporation to buy its traded shares, which are called treasury shares. This policy thus leads to the creation of so-called shares cash and stock prices are mostly greater than the price prevailing in the market.

There is another method, which is called the repurchasing of the target shares through management corporation practices, such as negotiating with shareholders who have large proportions of shares, to thwart control over the corporation's shares. Corporations usually negotiate with some investors to the Foundation when the market share price is less than its true value. The stock repurchase policy has witnessed staggering growth in the United States and Europe.

\subsubsection{Quality Distributions and Bond Dividends}

This policy is also called distributions of quality in which the management of the corporation makes distributions of goods, real estate, investments or bonds in place of cash distributions. Corporations resort to this type of distribution when they have liquidity problems (the lack of necessary liquidity), but this type of distribution is not desired by shareholders as cash dividend distributions allow greater freedom for contributors to meet their needs and wants.

\section{Literature Review}

Choosing the appropriate dividend policy is one of the important factors for assessing corporate performance. The behaviour of the dividend policy is one of the most debatable issues in financial literature and still maintains a noticeable place in emerging markets (Hafeez et al., 2018). Few studies have investigated the effect of dividend policy on financial performance, especially in emerging countries. Enekwe et al., (2015) tested the impact of dividend pay-out on the performance of cement companies in Nigeria over 12 years, 
using three variables to measure company performance: return on capital employed (ROCE); return on assets (ROA) and return on equity (ROE) as dependent variables and dividend pay-out ratio (DPR) as the independent variable to measure dividend policy. The result detected a strong relation between dividend pay-out ratio (DPR) with all of the dependent variables (ROCE, ROA and ROE). Chelimo and Kiprop (2017) also aimed to study how dividend policy effects shares prices for insurance companies. Dynamic regression analysis was used to establish the relationship between dividend policy and share price. The result revealed that dividend distribution, dividend yield, earnings per share and inflation have a common importance in predicting the value of the share price. The same result was achieved by Nishat and Irfan (2004) who detected that dividend policy measured through dividend yield and pay-out ratio both had important effects on share price volatility.

Hafeez et al. (2018) applied a panel data regression model using ROA and ROE to measure performance and dividend pay-out ratio and earnings per share to measure dividend policy. They discovered that dividend policy is enough to explain and calculate firm performance. Farrukh et al., (2017) employed two variables, dividends per share and dividend yield, to measure dividend policy and return on equity as a measure of firm performance. According to a regression result, they detected that dividend policy has an important effect on firm performance. Rehman and Hussain (2013) found that the return on asset ratio is significantly affected by the dividend pay-out ratio. In addition, Amidu (2007) found a positive relation between return on assets and dividend policy and that the relation between return on assets and dividend pay-out ratio with leverage was negative.

Yegon et al. (2014) found a positive relation between dividend policies and firm profitability. Simon-Oke and Ologunwa (2016) detected that return on investment was very crucial and affected firm performance positively. Ebire et al. (2018) determined that that dividend pay-out ratio positively affected firm performance. Habumugisha and Mulyungi (2018) noticed a strong positive relation between dividend pay-out and dividends per share with stock price performance. Widiyanti et al.'s (2019) results indicated that some factors (dividend policy) have negative effects on earnings per share. Anandasayanan and Thirunavukkarasu (2016) used dividend pay-out ratio and dividend yield to measure dividend policy and used ROE and ROA to measure company performance. Their results indicated a significant impact of dividend policies on organisation performance. Manneh and Naser (2015), Cristea and Cristea (2017) revealed that dividend policy is positively and significantly associated with corporate profitability and negatively with leverage. Al-Sa'eed (2018), on the other hand, used the following variables as a proxy for measuring firm performance (dependent variable): Tobin's Q, ROA, ROE, NPM and Dividends measured by dividend yield. His results indicated dividends yield has a significant positive impact on firm performance.

Dividend policy and its impact on company performance have played an important role. In the literature survey, some studies detected a significant role of dividends on performance (e.g., Ebire et al., 2018; Farrukh et al., 2017; Anandasayanan \& Thirunavukkarasu, 2016; Enekwe et al., 2015; Yegon et al., 2014; Rehman \& Hussain, 2013; Amidu, 2007); other studies revealed that dividends have a constructive impact on performance; still others detected a negative impact of dividends on performance; and some researchers found an insignificant association between dividends and performance (Amidu, 2007; Kapoor et al., 2010; Widiyanti et al., 2019). Based on the previous literature, we really need to make sure of the impact of dividend policy on performance. Is it positive or negative or is there no impact on performance? This has led to more research on this issue to achieve consensus on this topic.

\section{Study Methodology}

This part of the paper defines the method by which the study sample was chosen and the variables identified, how they were measured and collected and the data analysis and testing techniques that were used in order to determine the nature of the impact of dividend policy on the financial performance for listed companies in ASE in the period of 2015-2019. The panel data methodology was applied which pooled panel data of observation into time series and crosssection units. Moreover, the study used simple and multiple linear regression models.

\subsection{Study Population and Sample}

The study population consists of all shareholding corporations listed in the ASE during the period 2015-2019. The study sample consists of manufacturing (industry) and service sectors of the Jordanian economy with a total of 92 companies, with a total of $460(92.5 \%)$ observations. This sample was also chosen based on the following considerations: listed on the ASE with shares traded during the study period; not facing any events that could have an effect on its financial position, such as integration, mergers, etc., during the study period; information available on the movement of its shares traded in the financial market during the test period; and data available about the corporation.

\subsection{Methods of Data Collection}

The necessary data was collected from the financial reports related to the corporations. Thus, it was obtained through the 
statistical reports issued by these corporations on an annual basis; from the companies and directory publications of the ASE on the official website of the ASE from 2015 to 2019; and from annual reports and market news that show the most important events faced by the corporations, such as mergers, filtering (bankruptcy), etc., with follow-up of any changes for these companies.

\subsection{Study Variables and Hypothesis Development}

The independent variable included in the study (dividend policy) was measured through dividend yield and dividend pay-out ratio, consistent with Anandasayanan and Thirunavukkarasu (2016), Farrukh et al. (2017) and Widiyanti et al. (2019) Dividend yield represents the sum of the annual distributions that a corporation pays to its shareholders on their investments. At the same time, it shows investment attractiveness in a corporation's shares. Dividend yield could also be represented by ROI for investors who do not prefer capital gains or long-term earnings. It is calculated as 'annual dividend per share' divided by current market value per share': Dividend Yield $=$ Dividends Per Share/ Market Stock Price. It measures the investor return that may be made from dividends alone which becomes part of the expected return on investment. The second technique used to measure dividend policy is dividend pay-out ratio, which compares the dividends paid by a company to its earnings to detect the significance relationship between dividends and earnings.

The part of earnings that is not paid out in dividends is used for reinvestment in new projects (growth projects) to generate future earnings. Investors who are interested in short-term earnings prefer to invest in companies with high dividend pay-out ratios. On the other hand, investors who prefer to have capital growth prefer to invest in companies with lower dividend pay-out ratios. So dividend pay-out could be computed through this equation: Pay-out = Dividends/ Net Income, which means the percentage of earnings that the company pays in dividends. If the net income is negative, the pay-out ratio cannot be computed.

Financial performance usually focuses on revenue and profit margins, and one of the key profit-based metrics is the 'net profit' measure. Net profit is calculated as an amount that must be converted into a proportion of revenue; that is, net profit margin For example, if the benchmark net profit margin for a particular industry is $40 \%$, the new company in the industry must work to reach or exceed this number $(40 \%)$ in order to compete. A 'gross profit margin' is a common measure of performance based on profit that measures revenue after deducting the expenses directly related to the production of goods.

There are special standards for each department that are not suitable for another department, known as the criteria for measuring and evaluating performance. Financial indicators are used to evaluate the company's performance, as the company's success depends on achieving revenue and the effective management of financial resources. Shareholders, investors and customers use financial data to evaluate the company's performance as well as its ability to grow and achieve profit, cost measurement, comparison of the proposed budget with the actual budget and other financial indicators to assess company health and profitability. There are many measures used in the literature to assess financial performance (Hindasah \& Nuryakin, 2020). The discussion that follows will highlight the means that are most used for this purpose: liquidity ratios. These ratios are used to measure the ability of the enterprise to meet short-term obligations.

Activity or asset management ratios: These indicate the efficiency of management in using assets to generate returns. There are a number of indicators used to measure the activity, which are: stock turnover, sale period, collection period, turnover of capital, turnover of fixed assets and turnover of total assets (assets).

Leverage ratios or debt management: This refers to the degree of financing the company has established through debt. The success of using finance by means of debt rather than owner financing means management has the ability to increase the return to shareholders. The indicators used for these ratios are total debt to total assets and the ratio of indebtedness to total financial capital.

Profitability ratios: These assess the efficiency and effectiveness of an enterprise in generating profits; if the enterprise does not obtain sufficient profit then its longterm survival will be threatened. The indicators used to measure these ratios are net profit margin on sales, return on investment, return on equity and earnings per share.

Evaluation ratios: These ratios aim to raise the market value of the enterprise's shares. The enterprise's share prices are related to the book value of one share. These ratios have a number of indicators, including share price to share per ordinary share and the market value of the share to the book value.

Growth rate: The growth period of the institution is measured in the framework of the growth of the national economy, represented by the growth of national income or gross national product or the growth of the sector in which the company operates. The indicators used are net sales growth, net income growth, profit growth per ordinary share and growth dividends divided by one ordinary share. The current study will apply the most important factors to measure financial performance through the use of profitability indicators (ROA and ROE), consistent with Freihat and Kanakriyah (2017); Ali et al. (2020), which reflect the performance of the foundation's share and its value through the period 2015-2019. 
The random error: This error is likely to exist for several different reasons, including those related to neglecting some independent variables that can affect the dependent variable, incorrect mathematical formulation of the model or the result of an error in both the collection of some data and the measurement of financial variables.

Statistical methods and tools used: This study relied on simple and multiple linear regression methods for testing and proving the validity of the study hypotheses when $(\alpha<0.05)$ with degree of confidence $(95 \%)$, and for this reason applied the following tests to ensure achieving the study's purposes: regression analysis, correlation (correlation matrix) and descriptive statistics.

This study seeks to test the following hypotheses:

H1: There is a strong association between dividend policy and return on assets.

H2: There is a strong association between dividend policy and return on equity

Dividend policy is measured by dividend yield and dividend pay-out ratios along with other control variables as mentioned before.

\subsubsection{Control Variables}

Control variables that were employed in the current study include firm size because large firms have the ability to pay more dividends (Phornlaphatrachakorn \& Khajit, 2020) (the firm size will be measured through the natural logarithm of total assets); the current ratio; and the leverage ratio. Current ratio represents current assets divided by current liabilities. While the leverage ratio shows the volume of external financing from short-term and long-term debts, creditors prefer low rates of savings because the lower the percentage, the higher the margin of safety, which means creditors can recover their dues in case of liquidation. This ratio is measured through total debts divided by total assets. To test the impact of dividend policy on financial performance, the study will test the effect of dividend policy on ROA and ROE for five years (2015-2019). The variable used as a proxy to measure the financial performance is return on assets (ROA) and return on equity (ROE) through applied pooled regression as detailed in the equation below.

The proposed estimated model for the multiple regression function of the variables under study is shown in the following equation. Estimate the multiple regression model and view the results:

A multiple regression model (pooled regression) was developed in order to reply to the study's hypotheses:

$$
\begin{aligned}
\mathrm{ROA}=\beta 0 & +\beta 1 \mathrm{DY}+\beta 2 \mathrm{DPR}+\beta 3 \mathrm{CRA}+\beta 4 \mathrm{LRA} \\
& +\beta 5 \mathrm{FSIZE}+\mathrm{e} . \\
\mathrm{ROE}=\beta 0 & +\beta 1 \mathrm{DY}+\beta 2 \mathrm{DPR}+\beta 3 \mathrm{CRA}+\beta 4 \mathrm{LRA} \\
& +\beta 5 \mathrm{FSIZE}+\mathrm{e} .
\end{aligned}
$$

Where:

ROA, ROE: Used as a proxy for Financial

Performance

DY: Dividend Yield

DPR: Dividend Pay-out Ratio

CRA: Current Ratio.

LRA: Leverage Ratio.

FSIZE: Firm Size.

$\beta 0$ : Intercept.

$\beta 1-5$ : Coefficients.

e: Error term.

Table 1: Study Variables and Methods to Measure Them

\begin{tabular}{|l|c|c|l|}
\hline Variable & Type & Code & \multicolumn{1}{|c|}{ Proxies } \\
\hline Return on Assets & Dependent & ROA & Proxy to measure Financial Performance \\
\hline Return on Equity & Dependent & ROE & Proxy to measure Financial Performance \\
\hline Dividend Yield & Independent & DY & Dividend Yield = Dividends per share / Stock price. \\
\hline Dividend Pay-out Ratio & Independent & DPR & $\begin{array}{l}\text { The dividends paid by a company compared to its } \\
\text { earnings. }\end{array}$ \\
\hline Current Ratio & Independent & CRA & Measured by current assets divided by current liabilities \\
\hline Leverage Ratio & Independent & LRA & Measured through total debts divided by total assets \\
\hline Firm Size & Independent & FSIZE & The natural logarithm of the total assets \\
\hline
\end{tabular}


Table 2: Study Variables and Methods to Measure Them

\begin{tabular}{|l|c|c|c|c|c|}
\hline & $\mathbf{N}$ & Minimum & Maximum & Mean & Std. Deviation \\
\hline ROA & 460 & -.2 .3 & .627 & 21.31250 & .26 \\
\hline ROE & 460 & .00 & 11.81 & 5.561 & 17.76 \\
\hline DY & 460 & .035 & .253 & .1424 & 18.42 \\
\hline DPR & 460 & .00 & 18.16 & 9.0858 & 9.37671 \\
\hline CRA & 460 & 0.83 & 10.25 & 5.2353 & .71527 \\
\hline LRA & 460 & .00 & 22.00 & .2236 & 2.65221 \\
\hline FSIZE & 460 & 12.34 & 19.40 & 15.5269 & 18.49 \\
\hline Valid N (list wise) & 460 & & & & \\
\hline
\end{tabular}

Now that we have defined the method and tools of the study, we will discuss the results and the analysis in order to reach the final result and compare it with the results of previous studies. Before building the model and testing its hypotheses, we present the study model Estimate the Multiple-Regression Model and show the results.

\section{Results}

\subsection{Descriptive Statistics}

Table 2 shows the ROA and ROE indicators used to measure performance for the companies that were surveyed. ROA indicated weak profitability, which reached to .62 with standard deviation (SD) .26; some companies achieved losses of 2.3 million. ROA shows the ability of the funds invested in the company to achieve net profit, with full coverage of operating and non-operating costs. This ratio measures the relationship between net profit and asset size and the ability of the dinar invested in the assets. ROE indicates the ability of the dinar invested by the company's shareholders to achieve profits. If this percentage does not reach the expected return, the shareholders transfer their money to other investments. The test values were between the range 0.00 to 11.8 million. These ratios are generally low, and this may be due to the financial and economic instability of companies, especially after the global financial crisis.

With respect to the Jordanian industrial companies included in the study sample, it indicates the poor performance of the management of investment of their assets to achieve profits. Leverage debts constitute approximately $22 \%$ which means highly leveraged companies that depend on debts to finance operations. Dividend yield during the study period ranges between zero and up to .25 with an average of $14 \%$. This percentage indicates that the share of the dividend reaches $25 \%$, which means that the investor will receive a cash return of $14 \%$. Dividend pay-out ratio during the study period ranges between zero and up to 18.9 million. The current ratio for surveyed companies ranges between .83 to 10.25 , which indicates problems in investing. The firm size range between 12-19 is due to the large difference in size from one company to another as a result of the difference in the size of the assets between these companies.

\subsection{Empirical Tests and Analysis}

This part presents the main results. The variables correlation matrix is illustrated in Table 3. Supplementary, Table 4 shows the multi-regression result for the study model (multiple regressions).

To make sure there were no multicollinearity problems, the VIF (variance inflation factors) test was done with the result that values were less than 10 as shown in Table 4, which means multicollinearity is not problematic. The F-Test aims to measure the validity of the model in general and the study result shows the model has the ability to explain $76.8 \%$ of financial performance because the adjusted $\mathrm{R}^{2}$ value was $76.8 \%$ demonstrating the model's suitability for deducing the financial performance. The independent variable displays that the following relation between dividend yield and the dividend pay-out ratio have a positive significant effect on financial performance (ROA and ROE), asserted through $(\mathrm{p}$-value $=.00<0.05)$.

Hence, this result is consistent with previous studies, such as those by Yegon et al. (2014), Manneh and Naser (2015), Cristea and Cristea (2017), Anandasayanan and Thirunavukkarasu (2016) and Habumugisha and Mulyungi (2018) and corresponds with the Bird-In-The-Hand Theory. This result also reduces agency costs which means that higher profit payments have reduced the required rate of return, thereby enhancing the company's value. Hence, it is evident that the dividend policy has a positive impact on corporate performance, even though this is not compatible with the results of a study by Narang (2018), which concluded that there was no statistically significant relationship between the policy of dividend distribution, the rate of return on assets and the rate 
of return on shareholder equity as measures of performance. On the other hand, there is a statistically significant positive relationship between company size and ROA and also ROE meaning the performance of companies is positively affected by the size of companies. Thus, the performance of large companies is higher than that of small companies, consistent with Al-Nawaiseh (2013) and inconsistent with Olawale and Lawal (2017). This means large companies will achieve more profit if compared with small companies.

Based on the results of the study model analysis, the results present a negative significant relation between leverage ratio and both ROA and ROE. As it appears from Table 3, this could be attributed to interest expenses that lead to decreases in profit which are reflected in ROA and ROE and may expose firms to financial problems consistent with Ramezanalivaloujerdi et al. (2015).

According to the first hypothesis, which speculates an association between the independent variables (DY, DPR) and ROA, it appears from Table 4 that the coefficient of the interaction variable of the dividend policy is positive and statistically significant at the level of $5 \%(\beta=.421$; P- Value $=.00<5 \%)$ and DPR $(\beta=.081 ; \mathrm{P}$ - Value $=.039<5 \%)$, respectively. This result is in line with Bird-In-The-Hand Theory. Accordingly, the first hypothesis will be accepted which means that the higher the number of new investments, the greater the company's profits. Thus, the hypothesis that supposes the financial distribution decision will affect the financial performance represented by ROA is correct, leading to acceptance of this hypothesis.

The second hypothesis expected a positive relation between dividend policy and financial performance proxied by ROE. Our findings confirm such a relationship ( $p$ - value $=.039<0.05)$, leading to the acceptance of the hypothesis as presented in Table 4. Pearson's correlation detected the absence of a significant relationship between the dividend distribution ratios and the liquidity ratio (CAR), but the control variable current ratio played a modified role on firm performance when deploying ROA and ROE, while the variable leverage ratio reported a significant negative impact on firm performance.

Table 3: Matrix Correlation Coefficients for the Study Variables

\begin{tabular}{|l|c|c|c|c|c|c|c|}
\hline E- views correlation & ROA & ROE & DY & DPR & CRA & LRA & FSIZE \\
\hline ROA & 1 & .461 & .98 & .014 & $.225^{* *}$ & $.461^{* *}$ & .031 \\
\hline ROE & .461 & 1 & .332 & .028 & $.448^{* *}$ & $.612^{* *}$ & .814 \\
\hline DY & .98 & .332 & 1 & .086 & .054 & .067 & $.339^{* *}$ \\
\hline DPR & .014 & .028 & .086 & 1 & .049 & $-.080-$ & $-.074-$ \\
\hline CRA & $.225^{* *}$ & $.448^{* *}$ & .054 & .049 & 1 & $.357^{* *}$ & .145 \\
\hline LRA & $.461^{* *}$ & $.612^{* *}$ & .067 & $-.080-$ & $.357^{* *}$ & 1 & $.229^{* *}$ \\
\hline FSIZE & .031 & .0814 & $.339^{* *}$ & $-.074-$ & .145 & $.229^{* *}$ & 1 \\
\hline
\end{tabular}

**. Correlation is significant at the 0.01 level (2-tailed).

*. Correlation is significant at the 0.05 level (2-tailed).

Table 4: Detects Multiple Regression Results for 2015 to 2019

\begin{tabular}{|c|c|c|c|c|c|c|c|c|c|c|c|c|c|}
\hline \multirow{2}{*}{ Variable } & \multicolumn{2}{|c|}{2015} & \multicolumn{2}{|c|}{2016} & \multicolumn{2}{|c|}{2017} & \multicolumn{2}{|c|}{2018} & \multicolumn{2}{|c|}{2019} & \multicolumn{2}{|c|}{ For all years } & \multirow[b]{2}{*}{ VIF } \\
\hline & coff & $p$-value & coff & $p$-value & coff & $p$-value & coff & $p$-value & coff & $p$-value & coff & $p$-value & \\
\hline ROA & 4.19 & .00 & 3.84 & .000 & 4.77 & .00 & 4.15 & .000 & 5.81 & .000 & 1.71 & .000 & 0.89 \\
\hline ROE & .225 & .00 & .381 & .000 & .118 & .00 & .769 & .000 & .423 & .008 & .015 & .000 & 1.09 \\
\hline DY & .846 & .00 & .685 & .000 & .279 & .00 & .941 & .000 & .611 & .006 & .421 & .000 & 1.24 \\
\hline DPR & .017 & .01 & .088 & .301 & .241 & .10 & .027 & .058 & .014 & .033 & .081 & .039 & 1.13 \\
\hline CRA & -.088 & .020 & -.131 & .538 & -.067 & .029 & -.077 & .028 & -.018 & .0181 & .641 & -.125 & 1.19 \\
\hline LRA & -.065 & .031 & -.342 & 453 & -.085 & .132 & -.061 & .022 & -.075 & .016 & -.65 & -.041 & 1.44 \\
\hline FSIZE & .156 & .00 & .106 & .156 & .183 & .15 & .014 & .244 & .221 & .016 & .112 & .071 & 1.14 \\
\hline $\mathrm{R}$ & \multicolumn{2}{|c|}{.788} & \multicolumn{2}{|c|}{.793} & \multicolumn{2}{|c|}{.893} & \multicolumn{2}{|c|}{.762} & \multicolumn{2}{|c|}{.792} & \multicolumn{2}{|c|}{78,8} & \\
\hline $\mathrm{R} 2$ & \multicolumn{2}{|c|}{.750} & \multicolumn{2}{|c|}{.768} & \multicolumn{2}{|c|}{.769} & \multicolumn{2}{|c|}{.76 .9} & \multicolumn{2}{|c|}{.77} & \multicolumn{2}{|c|}{76.8} & \\
\hline $\begin{array}{l}\text { Model } \\
\text { F-test }\end{array}$ & \multicolumn{2}{|c|}{12.931} & \multicolumn{2}{|c|}{15.667} & \multicolumn{2}{|c|}{16.362} & & 7.811 & \multicolumn{2}{|c|}{14.332} & \multicolumn{2}{|c|}{$\begin{array}{c}41.672 \\
P=0.000\end{array}$} & \\
\hline
\end{tabular}




\section{Conclusion, Recommendations and Future Studies}

This study aimed to test the impact of dividend policy on company performance of Jordanian public shareholding companies (industrial and service sectors) to enable policymakers and regulatory bodies to understand the main features of corporate governance and dividend evaluation practices in Jordanian companies. In addition, the study aimed to provide valuable strategies to enable stock market participants to understand the role of dividend policy and how it can affect company performance.

In this study, we tried to answer the study question (problem) that related to the effect of the dividend policy on company performance. The study concluded that the distribution policy does have an effect on the performance of industrial and service companies in the Amman Financial Market during the period from 2015-2019 through the effect of dividend yield and dividend pay-out ratio (independent variables) on the performance (dependent variable) at a significance level of 0.05 , while the results of the multiple regression test revealed that there is a significant effect of the dividends policy on the performance of the shares of the listed companies. The reason can be due to investor preference for firms that have more dividends instead of retained earnings, meaning that investors tend to have more liquidity and this meets the needs of investors in the Amman Financial Market. The results of the study reveal that the dividend distribution policy is the policy concerned with assessing performance through return on assets and return on equity, and that most of the institutions make dividends in order to get more money by buying the company's shares consistent with Kanakriyah (2016).

More importantly, this study not only detected a significant impact of dividend policy on firm performance of the study sample (manufacturing and service companies), but also detected that the study variables (dividend yield [DY] and dividend pay-out ratio [DPR]) have played a significant role in predicting firm performance. On the other hand, the control variable, firm size, has a significant role in company performance, while CRA (Current Ratio) played a moderate role in firm performance and leverage ratio played a negative relation with both ROA and ROE. The study found that ROA and ROE are the most representative indicators as proxies for firm performance. Based on previous findings, the study also discovered that the variables chosen were suitable indicators to calculate firm performance which enabled the researcher to get brilliant and strong results.

Furthermore, study results present a strong relation between all examined variables that explain firm performance through the $\mathrm{R}$ value computed (78.8) for the study model, which indicates that the model has the ability to interpret $78.8 \%$ of variation in financial performance (Kanakriyah, 2020). These important results detect an influential relationship between dividend yield and dividend pay-out ratio on one side and performance on the other side. This model will be used as a plan to help company managers evaluate dividend policies and will also be helpful to investors to understand management's vision. However, this model will be more suitable for emerging economies and should not be considered for developed economies. These findings will also be an important reference for future studies

The researcher recommends that corporate management search for investments with high profitability as well as to benefit from external financing because it provides the necessary funds so that the company maintains a rate of growth characterised by stability which enables it to distribute cash to shareholders.

Finally, the study advises future research to take the current variables into consideration and to apply more control variables to enhance and make the results tougher and stronger, such as board structure, earnings per share, governance techniques, capital structure and internal or external auditing, risk and corporate profitability.

\section{References}

Ali, Q., Salman, A., Yaacob, H., Zaini, Z., \& Abdullah, R. (2020). Does Big Data Analytics Enhance Sustainability and Financial Performance? The Case of ASEAN Banks. Journal of Asian Finance, Economics, and Business, 7(7), 1-13. https://doi. org/10.13106/jafeb.2020.vol7.no7.001

Al-Nawaiseh, M. (2013). Dividend policy and ownership structure: an applied study on industrial companies in Amman Stock Exchange. Journal of Management Research, 5(2), 83-106.

Al-Sa'eed, M. T.A.A. (2018). The impact of ownership structure and dividends on firm's performance: evidence from manufacturing companies listed on the Amman stock exchange. Australasian Accounting, Business and Finance Journal, 12(3), 107-126.

Amidu, M. (2007). How does dividend policy affect performance of the firm on Ghana Stock Exchange? Investment Management and Financial Innovations, 4(2), 103-112.

Anandasayanan, S., \& Thirunavukkarasu, V. (2016). Dividend policy and corporate profitability econometric analysis of listed manufacturing firms in Sri Lanka. International Journal of Commerce and Management Research, 2(1), 53-58.

Chelimo, J. K., \& Kiprop, S. K. (2017). Effect of dividend policy on share price performance: a case of listed insurance companies at the Nairobi securities exchange, Kenya. International Journal of Accounting, Finance and Risk Management, 2(3), 98-106.

Cristea, C., \& Cristea, M. (2017). Determinants of corporate dividend policy: evidence from Romanian listed companies. In: MATEC Web of Conferences (Vol. 126, p. 04009). EDP Sciences. 
Ebire, K., Mukhtar, S. S., \& Onmonya, L. (2018). Effect of dividend policy on the performance of listed oil and gas firms in Nigeria. International Journal of Scientific and Research Publications, 8(6), 289-302.

Enekwe, C. I., Nweze, A. U., \& Agu, C. I. (2015). The effect of dividend payout on performance evaluation: Evidence of quoted cement companies in Nigeria. European Journal of Accounting, Auditing and Finance Research, 3(11), 40-59.

Farrukh, K., Irshad, S., Khakwani, M. S., Ishaque, S., \& Ansari, N. Y. (2017). Impact of dividend policy on shareholders wealth and firm performance in Pakistan. Cogent Business \& Management, 4(1), 1408208

Freihat, A. R. F., \& Kanakriyah, R. (2017). Impact of R\&D expenditure on financial performance: Jordanian evidence. European Journal of Business and Management, 9(32), 73-83.

Habumugisha, T., \& Mulyungi, P. (2018). Effect of corporate dividend policy on performance of stock prices in Rwanda Stock Exchange. Case study of Bank of Kigali as listed on Rwanda Stock Exchange (2011-2016). International Journal of Research in Management, Economics and Commerce, 8(5), 183-193.

Hafeez, M. M., Shahbaz, S., Iftikhar, I., \& Butt, H. A. (2018). Impact of Dividend Policy on Firm Performance. International Journal of Advanced Study and Research Work, 1(4), 1-5.

Hindasah, L., \& Nuryakin, N. (2020). The Relationship between Organizational Capability, Organizational Learning and Financial Performance. Journal of Asian Finance, Economics and Business, 7(8), 625-633. https://doi.org/10.13106/ jafeb.2020.vol7.no8.625

Kanakriyah, R. (2020). Model to Determine Main Factors Used to Measure Audit Fees. Academy of Accounting and Financial Studies Journal, 24(2), 1-13.

Kanakriyah, R. (2016). Voluntary Disclosure and Its Effect on the Quality of Accounting Information According to Users' Perspective in Jordan. American Journal of Business, Economics and Management, 4(6), 134-146.

Kapoor, S., Mishra, A., \& Anil, K. (2010). Dividend policy determinants of Indian services sector: a factorial analysis. Paradigm, 14(1), 24-41.

Lintner, J., \& Gordon, M. (1974). Thirty-third Annual Meetings American Finance Association San Francisco, California, December 28-30, 1974. The Journal of Finance, 29(4), 13561361.
Manneh, M. A., \& Naser, K. (2015). Determinants of corporate dividends policy: Evidence from an emerging economy. International Journal of Economics and Finance, 7(7), 229-239.

Miller, M. H., \& Modigliani, F. (1961). Dividend policy, growth, and the valuation of shares. Journal of Business, 34(4), 411-433.

Narang, M. (2018). Impact of capital structure on firm performance: A study of listed firms on national stock exchange. International Journal of Advanced Educational Research, 3(1), 251-254.

Nishat, M., \& Irfan, C. M. (2004). Dividend policy and stock price volatility in Pakistan. In: Pide-19th annual general meeting and conference (pp. 13-15).

Olawale, L. S., Ilo, B. M., \& Lawal, F. K. (2017). The effect of firm size on performance of firms in Nigeria. The IEB International Journal of Finance, (15), 68-87.

Phornlaphatrachakorn, K., \& Khajit, N. K. (2020). Strategic Management Accounting and Firm Performance: Evidence from Finance Businesses in Thailand. Journal of Asian Finance, Economics and Business, 7(8), 309-321. https://doi. org/10.13106/jafeb.2020.vol7.no8.309

Ramezanalivaloujerdi, R., Rasiah, D., \& Narayanasamy, K. (2015). Corporate capital structure and performance of listed construction companies in Malaysia from 2005-2009. International Business Management, 9(3), 191-199.

Rehman, M. U., \& Hussain, A. (2013). Impact of dividend policy on performance of firms having stocks listed in an emerging stock market. Asian Journal of Empirical Research, 3(1), 2029.

Simon-Oke, O. O., \& Ologunwa, O. P. (2016). Evaluation of the effect of dividend policy on the performance of corporate firms in Nigeria. FUTA Journal of Management and Technology, 1(1), 121-136.

Widiyanti, M., Adam, M., \& Isnurhadi, I. (2019). Effect of Company Performance on Earing per Share with Dividend Payout Ratio as Intervening Variable in LQ 45 Companies. Acta Universitatis Danubius. Economica, 15(4).

Yegon, C., Cheruiyot, J., \& Sang, J. (2014). Effects of dividend policy on firm's financial performance: Econometric analysis of listed manufacturing firms in Kenya. Research Journal of Finance and Accounting, 5(12), 136-144. 